\title{
Hubungan Pembelajaran Daring Terhadap Minat Belajar Siswa SMA
}

\author{
Yulia Suriyanti \\ STKIP Persada Khatulistiwa \\ suryantiyuli@yahoo.co.id
}

\begin{abstract}
This study aims to determine the relationship between online learning and student interest in learning at SMA Nusantara Indah. The research approach is quantitative and the type of research is survey. The research population was all students of SMA Nusantara Indah Sintang. The sampling technique is proportionate stratified random. Methods of data collection using questionnaires and documentation. Data analysis by means of: preliminary analysis by calculating the percentage, further analysis by calculating the product moment correlation formula from Karl Pearson and continued with the t test. The results showed that there was no significant relationship between the implementation of online learning on the students' interest in learning at SMA Nusantara Indah with a t-count value of 0.876. This shows that there is no significant relationship between interest in learning and online learning

Keywords: interest to learn; online learning
\end{abstract}

\begin{abstract}
ABSTRAK
Penelitian ini bertujuan untuk mengetahui hubungan pembelajaran daring dengan minat belajar siswa di SMA Nusantara Indah. Pendekatan penelitian adalah kuantitatif dan jenis penelitian adalah survei. Populasi penelitian adalah seluruh siswa SMA Nusantara Indah Sintang. Teknik sampling proportionate Stratified Random. Metode pengumpulan data menggunakan angket dan dokumentasi. Analisis data dengan cara: analisis pendahuluan dengan perhitungan persentase, analisis lanjutan dengan perhitungan rumus korelasi product moment dari Karl Pearson dan dilanjutkan dengan uji $t$. Hasil penelitian menunjukkan tidak ada hubungan yang signifikan pelaksanaan pembelajaran daring terhadap minat belajar siswa SMA Nusantara Indah dengan nilai $t$ hitung sebesar 0,876. Hal tersebut menunjukkan tidak ada hubungan signifikan antara minat belajar dan pembelajaran daring.
\end{abstract}

Kata Kunci: minat belajar; pembelajaran daring

Submitted May 12, 2021 | Revised Jun 04, 2021 | Accepted Jun 07, 2021

\section{Pendahuluan}

Era globalisasi adalah era di mana segala sesuatu selalu berkembang dan mengalami kemajuan sehingga memudahkan manusia untuk beraktivitas. Salah satu bidang kemajuan di era ini adalah kemajuan bidang teknologi internet. Perkembangan teknologi internet akan dapat mempengaruhi berbagai aspek kehidupan manusia, salah satunya adalah aspek pendidikan (Arsyad, 2006: 7) Adanya Pandemi Covid-19, menjadikan proses pembelajaran siswa dipindahkan dari sekolah ke rumah. Peralihan cara pembelajaran ini memaksa berbagai pihak untuk mengikuti alur agar pembelajaran tetap berlangsung, yaitu pemanfaatan teknologi. Pembelajaran ini disebut dengan pembelajaran daring (dalam jaringan)

Pembelajaran daring adalah pembelajaran yang diselenggarakan melalui jaringan web. Setiap mata kuliah/ pelajaran menyediakan materi dalam bentuk rekaman video atau slideshow, dengan tugas-tugas mingguan yang harus dikerjakan dengan batas waktu pengerjaan yang telah ditentukan dan beragam sistem penilaian (Bilfaqih, 2012).

Pembelajaran daring merupakan sebuah inovasi pendidikan yang melibatkan unsur teknologi informasi dalam pembelajaran (Agustika, 2020; Sepita \& Suryanti, 2020; Loviana \& Baskara, 2020) Pembelajaran daring merupakan sistem pendidikan jarak jauh dengan sekumpulan metoda pengajaran dimana terdapat aktivitas pengajaran yang dilaksanakan secara terpisah dari aktivitas belajar. pembelajaran daring diselenggarakan melalui jejaring internet dan web 2.0 (Alessandro, 2018), artinya bahwa penggunaan pembelajaran daring melibatkan unsur teknologi sebagai sarana dan jaringan 
internet sebagai sistem. Pembelajaran daring memberikan manfaat dalam membantu menyediakan akses belajar bagi semua orang, sehingga menghapus hambatan secara fisik sebagai faktor untuk belajar dalam ruang lingkup kelas, bahkan hal tersebut dipandang sebagai sesuatu yang efektif untuk diterapkan khususnya dalam perguruan tinggi, akan tetapi menurut Pilkington (2018) tidak bisa dipungkiri bahwa tidak semua pembelajaran dapat dipindahkan ke dalam lingkungan pembelajaran secara online.

Menurut Rusman (2011) setidaknya harus ada prinsip urtama dalam pembelajaran berbasis daring daring di antaranya: 1)Interaksi yang berarti kapasitas komunikasi dengan orang lain yang tertarik pada topik yang sama atau menggunakan pembelajaran berbasis daring daring. Dalam pembelajaran jarak jauh atau pembelajaran daring sampai saat ini, hanya efektif dalam mengerjakan penugasan yang diberikan oleh guru ke siswa (Ashari, 2020). Sedangkan dalam hal pembelajaran untuk memahami konsep sampai refleksi tidak dapat berjalan dengan baik. Dalam lingkungan belajar, interaksi berarti kapasistas berbicara baik antar peserta maupun antara peserta dengan instruktur. Interaksi membedakan antara pembelajaran berbasis daring daring dengan pembelajaran berbasis komputer (Computer-Based Instruction). Hal ini berarti bahwa mereka yang terlibat dalam pembelajaran berbasis daring daring tidak berkomunikasi dengan mesin, melainkan dengan orang lain (baik peserta maupun tutor) yang kemungkinan tidak berada pada lokasi dengan waktu yang sama. Interaksi tidak hanya menyediakan hubungan antar manusia, tetapi menyediakan keterhubungan isi, dimana setiap orang dapat membantu antara satu dengan yang lain untuk memahami isi materi dengan berkomunikasi. Hal tersebut menciptakan lapisan belajar terdalam yang tidak bisa diciptakan oleh pengembangan media; 2 ) Ketergunaan yaitu bagaimana bisa pembelajaran yang berbasis Daring Daring diaktualisasikan. Terdapat dua elemen penting dalam prinsip ketergunaan, yaitu konsistensi dan kesederhanaan. Intinya adalah bagaimana perkembangan pembelajaran berbasis Daring Daring ini menciptakan lingkungan belajar yang konsisten dan sederhana, sehingga siswa tidak mengalami kesulitan baik dalam proses pembelajaran maupun navigasi konten (materi dan aktivitas belajar lain).

Beberapa penelitian terdahulu telah dilakukan yang terkait dengan dampak pembelajaran daring. Dari penelitian-penelitian tersebut diperoleh temuan bahwa pembelajaran daring memberikan pengaruh yang positif terhadap proses dan hasil pembalajaran, diantaranya meningkatnya motivasi belajar siswa (Kurnianto \& Rahmawati, 2020; Rahma \& Safarati, 2021; Juliya \& Herlambang, 2021; Syafari \& Montessori, 2021) dan hasil belajar siswa (Sobron, et al, 2019; Nugraha, et al, 2020). Di samping itu, hasil penelitian menunjukan pembelajaran daring berpengaruh terhadap minat belajar siswa (Jusmawati, et al, 2020; Jamil \& Aprilisanda, 2020; Sijabat, et al, 2020) namun penelitianpenelitian tersebut semuanya mengambil sampel mahasiswa perguruan tinggi. Adapun penelitian ini berfokus pada hubungan pembelajaran daring dengan minat belajar dengan sampel siswa SMA.

Minat belajar merupakan sikap ketaatan dalam kegiatan proses belajar,baik yang menyangkut perencanaan jadwal belajar yang dimilikinya maupun inisiatif dirinya sendiri melakukan usaha tersebut dengan bersunggguh-sungguh dalam belajar (Andriani \& Rasto, 2019). Minat termasuk faktor intrinsik yang dapat berpengaruh terhadap hasil belajar seseorang. Apabila dia berminat pada suatu mata pelajaran, maka akan cenderung bersungguh-sungguh dalam mempelajari pelajaran tersebut. Sebaliknya, sesorang yang kurang berminat terhadap suatu pelajaran, maka ia akan cenderung enggan mempelajari pelajaran (Heri, 2019).

Dari latar belakang di atas, maka penelitian ini bertujuan untuk mengetahui hubungan pembelajaran daring dengan minat belajar siswa. Penelitian ini diharapkan bermanfaat bagi para pendidik dalam melaksanakan pembelajaran daring khususnya selama pandemi ini. 


\section{Metode Penelitian}

Penelitian ini melibatkan dua variabel, yaitu variabel bebas dan variabel terikat. Variabel bebas dalam penelitian adalah pembelajaran daring dan variabel terikat dalam penelitian ini adalah minat belajar siswa. Instrumen penelitian adalah angket dan dokumentasi. Populasi berjumlah 149 siswa dan teknik pengambilan sampel adalah Proportionate Stratified Random Sampling yaitu tehnik pengambilan sampel sedemikian rupa sehingga semua subkelompok pada populasi diwakili pada sampel dengan perbandingan sesuai dengan jumlah yang ada dalam populasi (Sumanto, 2014: 204). Rumus yang digunakan adalah Taro Yaname dan Slovin apabila populasi sudah diketahui, maka sampel yang terpilih berjumlah 45 siswa. Tekni analisis data dengan cara: analisis pendahuluan dengan perhitungan persentase, analisis lanjutan dengan perhitungan rumus korelasi product momentdari Karl Pearson dan dilanjutkan dengan uji t.

\section{Hasil dan Pembahasan}

Penelitian ini bertujuan untuk mengetahui hubungan pembelajaran daring dengan minat belajar siswa. Untuk tujuan tersebut dikumpulkan data tentang pelaksanaan pembelajaran daring dan minat belajar siswa melalui metode observasi dan angket. Data-data tersebut selanjutnya dianalisis dengan teknik regresi dan korelasi.

Dari perhitungan regresi diperoleh hasil $\mathrm{a}=63,43$ dan nilai $\mathrm{b}=2495,6$ sehingga persamaan regresi kedua variabel tersebut $\hat{Y}=a+b$ atau $\hat{Y}=63,43+2495,6$ nilai pada $b=2495,6$ artinya koefesien regresi kearah Positif menjauhi 1 . Semakin besar nilai koefesien regresi, maka kontribusi perubahan semakin besar pula artinya jika Lingkungan Belajar siswa meningkat 1, maka minat belajar siswa akan menurun sebesar 2495,6.

Analisa untuk menganalisis ada tidaknya korelasi antara pembelajaran daring dengan minat belajar siswa dilakukan analisis korelasi. Dengan rumus Product Momenct didapat nilai korelasi antara pembelajaran daring dengan minat belajar siswa ialah sebesar 0,296 sedangkan nilai $r_{\text {tabel }}$ 0,632 dengan batas signifikan 5\% yang artinya nilai pada $r_{\text {hitung }}$ lebih kecil dari pada $r_{\text {tabel }}$ yakni 0,296 $\leq$ 0,632. Dengan demikian dapat disimpulkan berdasarkan hipotesis yang diajukan bahwa Ho diterima pada taraf signifikan 5\% sedangkan $\mathrm{Ha}$ ditolak yang berarti tidak terdapat korelasi yang signifikan antara pembelajaran daring dengan minat belajar siswa. Berdasarkan interpretasi koefisien korelasi $r$ yang dinyatakan bahwa untuk nilai korelasi sebesar 0,296 termasuk dalam katagori yang rendah. Jadi dapat disimpulkan tidak terdapat korelasi yang signifikan antara pembelajaran daring dengan minat belajar siswa SMA Nusantara Indah Sintang.

Untuk melihat pengaruh pembelajaran daring terhadap minat belajar, dilakukan perhitungan dengan menggunakan koefisien determinasi. Hasil perhitungan dengan koefisisen determinasi diperoleh dengan nilai $\mathrm{r}$ sebesar $8,7 \%$ yang berarti bahwa hubungan pembelajaran daring siswa dengan minat belajar siswa SMA Nusantara Indah Sintang sebesar 8,7\% sedangkan sisanya sebesar 91,3\% dipengaruhi yang tidak diteliti seperti oleh peneliti misalnya perhatian, bakat, dan fasilitas sekolah.

Untuk membuktikan sejauh mana tingkat hubungan antara variabel $\mathrm{X}$ dan $\mathrm{Y}$, dilakukan perhitungan dengan uji t. Hasil perhitungan diperoleh nilai $t_{\text {hitung }}$ sebesar 0,876 dimana pada taraf kepercayaan atau signifikan $0,05 \%$ derajat kebebasan $(\mathrm{dk})=\mathrm{n}-2, \mathrm{dk}=10-2=8$ untuk harga $t_{\text {tabel }}$ sebesar 2,306 hasil menunjukkan bahwa $t_{\text {hitung }} \leq t_{\text {tabel }}(0,876 \leq 2,306)$ dengan demikian berdasarkan kriteria pengujian yang telah ditetapkan Ho diterima karena $t_{\text {tabel }}$ lebih besar dari pada $t_{\text {hitung }}$ dan $\mathrm{Ha}$ ditolak karena $t_{\text {hitung }}$ lebih kecil dari pada $t_{\text {tabel }}$ jadi dapat disimpulkan tidak terdapat hubungan yang signifikan antara pembelajaran daring siswa dengan minat belajar siswa SMA Nusantara Indah Sintang dari perhitungan uji t diatas bahwa $t_{\text {hitung }}$ lebih kecil dari $t_{\text {tabel }}$ yaitu $0,876>2,306$. 
Dari pembuktian hipotesis dengan perhitungan uji t menunjukkan bahwa tidak adanya hubungan yang signifikan antara pembelajaran daring siswa dengan minat belajar siswa SMA Nusantara Indah Sintang dan Ho diterima karena pada perhitungan $t_{\text {hitung }}$ menunjukkan hasil yaitu 0,876 sedangkan $t_{\text {tabel }}$ sebesar 2,306. Hal ini bertolak belakang hasil penelitian Jusmawati, et al, (2020), Jamil \& Aprilisanda (2020), dan Sijabat, et al, (2020) yang justru memperoleh hasil sebaliknya, dimana pembelajaran daring berpengaruh terhadap minat mahasiswa di perguruan tinggi.

\section{Kesimpulan}

Hasil penelitian menunjukkan nilai korelasi yang rendah, sehingga dapat disimpulkan tidak adanya hubungan yang signifikan antara pelaksanaan pembelajaran daring siswa dengan minat belajar siswa SMA Nusantara Indah Sintang.

\section{Daftar Pustaka}

Agustika, G. N. S. (2020). Dramatik Pembelajaran Daring pada Masa Pandemi Covid-19. MIMBAR PGSD Undiksha, 8(3).

Alessandro, B. (2018). Digital Skills and Competence, and Digital and Online Learning. Turin: European Training Foundation.

Ashari, M. (2020). Proses Pembelajaran Daring di Tengah Antisipasi Penyebaran Virus Corona Dinilai Belum Maksimal. 20 Maret. https://www.pikiran-rakyat.com/pendidikan/pr01353818/proses-pembelajaran-daring-di-tengah-antisipasi-penyebaran-virus-corona-dinilaibelum-maksimal.

Andriani, R., \& Rasto, R. (2019). Motivasi belajar sebagai determinan hasil belajar siswa. Jurnal Pendidikan Manajemen Perkantoran, 4(1), 80. https://doi.org/10.17509/jpm.v4i1.14958.

Arsyad, Azhar. (2006). Media Pembelajaran. Jakarta: PT. Rajagrafindo Persada

Asrul \& Afil, Moh. (2020). Dampak Pembelajaran Online Terhadap Minat Belajar Siswa Pada Masa Pandemi Covid-19 Di Sekolah SMPN Satap 1 Ladongi. http://www.fkipumkendari.ac.id/assets/upload/plp_magang/7a975346bf32978963b527a0c 87a08d5.pdf.

Bilfaqih, Yusuf. (2012). Esensi Pengembangan Pembelajaran Daring.Yogyakarta: Deepublish.

Heri, T. (2019). Meningkatkan Motivasi Minat Belajar Siswa. Rausyan Fikr: Jurnal Pemikiran dan Pencerahan, 15(1).

Jamil, S. H., \& Aprilisanda, I. D. (2020). Pengaruh pembelajaran daring terhadap minat belajar mahasiswa pada masa pandemik covid-19. Behavioral Accounting Journal, 3(1), 37-46.

Juliya, M., \& Herlambang, Y. T. (2021). Analisis Problematika Pembelajaran Daring Dan Pengaruhnya Terhadap Motivasi Belajar Siswa. Genta Mulia: Jurnal Ilmiah Pendidikan, 12(1).

Jusmawati, J., Satriawati, S., \& Sabillah, B. M. (2020). Pengaruh Pembelajaran Berbasis Daring Terhadap Minat Belajar Mahasiswa Pgsd Unimerz Pada Mata Kuliah Pendidikan Matematika. JKPD (Jurnal Kajian Pendidikan Dasar), 5(2), 106-111.

Kurnianto, B., \& Rahmawati, R. D. (2020). Hubungan Pola Asuh Orang Tua terhadap Motivasi Belajar Siswa Pada Pembelajaran Daring Masa Pandemi. In Seminar Pendidikan Nasional (SENDIKA) (Vol. 2, No. 1).

Loviana, S., \& Baskara, W. N. (2020). Dampak pandemi covid-19 pada kesiapan pembelajaran tadris matematika IAIN Metro Lampung. Epsilon: Jurnal Pendidikan Matematika, 2(1), 61-70.

Nugraha, S. A., Sudiatmi, T., \& Suswandari, M. (2020). Studi pengaruh daring learning terhadap hasil belajar matematika kelas iv. Jurnal Inovasi Penelitian, 1(3), 265-276. 
Pilkington, O. A. (2018). Active Learning for an Online Composition Classroom : Blogging as an Enhancement of Online Curriculum. Journal of Educational Technology Systems, 47(2), 114.

Rachiim, Elvania. (2020). Hubungan Pelaksanaan Pembelajaran Daring dengan Minat Belajar Siswa MI Pada Masa Pandemi Covid-19 di Desa Krincing Secang Magelang Tahun 2020. http://erepository.perpus.iainsalatiga.ac.id/9814/1/ELVANIA\%20RACHIM\%2023040160 108.pdf.

Rahma, R., \& Safarati, N. (2021). Dampak Pembelajaran Daring Terhadap Motivasi Belajar Mahasiswa Selama Pandemic Covid 19. Genta Mulia: Jurnal Ilmiah Pendidikan, 12(1).

Sepita, S. F., \& Suryanti, S. (2020). Pengaruh Pembelajaran Daring Terhadap Hasil Belajar Kognitif Mahasiswa Pada Mata Kuliah Limnologi. Journal of Research and Education Chemistry, 2(2), 102102.

Sijabat, A., Sianipar, H. F., \& Siahaan, T. M. (2020). Pengaruh Pembelajaran Daring Terhadap Minat Belajar Mahasiswa Pendidikan Fisika Uhkbpnp Pada Matakuliah Fisika Umum. In Proceeding National Conference: Education, Social, Science, and Humaniora (Vol. 2, No. 1, pp. 84-88).

Sobron, A. N., Bayu, B., Rani, R., \& Meidawati, M. (2019). Pengaruh Daring Learning terhadap Hasil Belajar IPA Siswa Sekolah Dasar. In Seminar Nasional Sains \& Entrepreneurship (Vol. 1, No. 1).

Syafari, Y., \& Montessori, M. (2021). Analisis Pembelajaran Daring Terhadap Motivasi Belajar Dan Prestasi Belajar Siswa Dimasa Pandemi Covid-19. Jurnal Basicedu, 5(3), 1294-1303. 